\title{
A PRISM-D rajzteszt alkalmazása a daganatos betegséggel összefüggő érzelmi és kognitív reprezentációk komplex vizsgálatára
}

\author{
Sándor Zita ${ }^{1,2}$. Csabai Márta dr. ${ }^{3}$ \\ 'Szegedi Tudományegyetem, Általános Orvostudományi Kar, Klinikai Orvostudományok Doktori Iskola, Szeged \\ ${ }^{2}$ Gál Ferenc Főiskola, Egészség és Szociális Tudományi Kar, Gyula \\ ${ }^{3}$ Szegedi Tudományegyetem, Bölcsészettudományi Kar, Pszichológiai Intézet, Szeged
}

\begin{abstract}
Bevezetés: Egy súlyos betegség lelki megélésének, egyéni értelmezésének a vizsgálata fontos feladat, ugyanis ezen tényezők befolyásolhatják a megküzdéses válaszokat, illetve a betegség pszichés és szomatikus kimenetelét. A klinikai gyakorlatban a maladaptív reakciók szúrése, illetve a pszichés intervenciók hatékony megtervezése érdekében olyan, széles körben alkalmazható mérőeszközre van szükség, mely a betegséggel összefüggő érzelmi és kognitív reprezentációkat gyorsan, mégis kellően részletesen méri.

Célkitüzés: Tanulmányunk célja a Pictorial Representations of Illness and Self Measure teszt általunk kifejlesztett rajztesztverziója (PRISM-D) és utótesztje alkalmazhatóságának vizsgálata volt a klinikai gyakorlatban, daganatos betegek körében.

Módszer: Vizsgálatunk során 150 fó, kezelés alatt álló daganatos beteggel vettük fel a Pictorial Representations of Illness and Self Measure rajztesztverzióját és annak utótesztjét.

Eredmények: A teszten nyerhető kvantitatív adatok alapján a vizsgált személyek nagymértékú, betegségtől való lelki szenvedést éltek meg, bár e tekintetben a mintára nagyfokú heterogenitás jellemző. A betegek többsége negatív érzéseket társított a betegségéhez, úgymint distressz, félelem, szomorúság, bizonytalanságérzés. A betegségreprezentációk tekintetében megjelent a betegség jelzésként, akadályként, megoldandó feladatként, küzdelemként, veszteségként, csapásként és személyes kudarcként való interpretálása. A betegséget szimbolizáló kör mérete és térbeli elhelyezkedése alapján azonosíthatók a betegséget tagadó, illetve bagatellizáló betegek, továbbá a betegséget rendkívül súlyosnak megélő személyek is. Ezen információk feltárása a betegséggel való megküzdés és a betegségviselkedés szempontjából kiemelten fontos.

Következtetések: Vizsgálatunk alapján a teszt mind a klinikai gyakorlatban, mind a kutatásokban jól alkalmazható, gyors és komplex információt nyújtó mérőeszköz, mely alkalmas a betegséggel összefüggő érzelmi és kognitív reprezentációk kvantitatív és kvalitatív mérésére kórházi környezetben, súlyos, akár verbálisan nehezen hozzáférhető betegek esetében is.
\end{abstract}

Orv Hetil. 2018; 159(48): 2021-2030.

Kulcsszavak: betegségpercepció, megküzdés, pszichológiai teszt, rajzolás, daganatos betegek

\section{Application of the PRISM-D drawing test to the complex examination of cancer-related emotional and cognitive representations}

Introduction: Studying the psychological experience and the individual interpretation of a serious illness is an important task, as these factors can affect coping strategies and the psychological and somatic outcome of the illness. In clinical practice, to screen out maladaptive reactions and to effectively plan the psychological interventions, we need measuring tools that can be applied among a wide range of patients and can measure the illness-related emotional and cognitive representations in detail.

Aim: The aim of our study was to examine the applicability of the drawing test version (PRISM-D) we developed from the Pictorial Representations of Illness and Self Measure test and its posttest in clinical practice among cancer patients. 
Method: We applied the Pictorial Representations of Illness and Self Measure drawing test and its posttest for 150 cancer patients undergoing hospital treatment.

Results: According to the quantitative data from the tests, patients underwent considerable suffering from illness, however, there was a large heterogeneity in the level of suffering in the sample. The majority of the patients in the sample associated negative feelings to their illness, such as distress, fear, sadness, uncertainty. As for illness representations, they interpreted their illness as a sign, a difficulty, a task to solve, a struggle, a loss, an adversity or a personal failure. The size and placement of the circle symbolizing the illness can be used to identify patient reactions to deny or understate illness as well as patients who experience their illness very seriously. This information is crucial in the understanding of illness behavior and the coping with illness.

Conclusions: Our study has supported this test as a measuring tool which is well applicable to quickly gain complex information both in clinical practice and in research, to measure illness-related emotional and cognitive representations, both quantitatively and qualitatively.

Keywords: illness perception, coping, psychological test, drawing, cancer patients

Sándor Z, Csabai M. [Application of the PRISM-D drawing test to the complex examination of cancer-related emotional and cognitive representations]. Orv Hetil. 2018; 159(48): 2021-2030.

(Beérkezett: 2018. május 4.; elfogadva: 2018. június 3.)

\section{Rövidítések}

$\mathrm{IPM}=$ (Illness Perception Measure) betegségpercepció; PRISM = Pictorial Representations of Illness and Self Measure teszt; PRISM-D = (Drawing version of Pictorial Representations of Illness and Self Measure) a Pictorial Representations of Illness and Self Measure teszt rajztesztverziója; SD = standard deviáció; SIS = (Self-Illness Separation $)$ Én-betegség távolság

Egy súlyos betegség a páciensek számára nem csupán testi, hanem számos lelki és szociális változással is együtt jár. A betegség következtében fellépó változásokra adott pszichés reakció, a betegség lelki megélése, valamint a betegséggel kapcsolatos mentális reprezentációk befolyásolhatják a rövid és hosszú távú testi, lelki és szociális felépülést [1-3].

A daganatos betegséggel való szembesülés a betegek többsége számára traumatikus esemény [4]. A diagnózissal való szembesülést követően gyakori reakció a lelki összeomlás, illetve a tudattalan elhárító mechanizmusok megjelenése [5]. A betegség vagy annak súlyosságának tagadása, elhárítása átmenetileg, a diagnózissal való szembesülés szakaszában csökkentheti ugyan az egyén lelki szenvedését, elnyomhatja szorongását, így rövid távon kedvező hatású lehet. A tartósan fennálló tagadás azonban, különösen a betegséggel való megküzdés időszakában, nagyon negatív következményekkel járhat, azon túl ugyanis, hogy megszakíthatja a stresszt keltő esemény lelki feldolgozásának folyamatát, gátolhatja az orvossal való együttmúködést vagy akár a gyógykezelésben való részvételt [6].

A betegségre adott érzelmi reakciók közül fontos szerepe van az emelkedett mértékü distressznek és szorongásnak, melyek negatívan befolyásolhatják a betegséghez való adaptációt, a megküzdését és akár a betegség lefo- lyását [7]. Lényeges az is, hogy a betegek milyennek látják betegségüket, miként értelmezik, intepretálják és értékelik azt. Ugyanis a betegség szubjektív percepciója, a beteg által kialakított egyedi betegségkép, betegségreprezentáció, illetve a betegség kimenetelével kapcsolatos elvárások szintén befolyásolják a páciensek megküzdéses válaszait és betegségviselkedését, így közvetve hatást gyakorolnak a betegség lefolyására $[8,9]$.

A kutatások és a tapasztalat ugyanakkor azt mutatja, hogy a betegség lelki megélése, illetve percepciója egyedi, még azonos betegpopuláción belül is nagy egyéni változatosságot mutat [10]. Éppen ezért szükséges az egyes betegek egyéni, szubjektív viszonyulásának vizsgálata, és maladaptív reakciók esetén egyénre szabott pszichés intervenció során módosítani a gyógyulást potenciálisan hátráltató lelki tényezőket.

Bár napjainkban számos mérôeszköz áll rendelkezésre a betegséggel kapcsolatos érzelmi és kognitív válaszok mérésére (például szorongás, depresszió, stressz, betegségreprezentáció, betegségteher), ezen mérőeszközök csak részben illeszthetôk a mindennapi klinikai gyakorlatba. Többségük csak jól verbalizáló, megfelelően együttmúködő személyek esetében alkalmazható, mely kritériumok súlyos betegséggel küzdő személyek esetében - akár a betegség tünetei, akár annak kezelése miatt - nem mindig teljesülnek. Továbbá, mivel a mérőeszközök többsége egy-egy szúk lelki dimenziót vizsgál, a beteg pszichés állapotának és kognícióinak feltárása több mérőeszköz alkalmazását teszi szükségessé, melyek felvétele és kiértékelése idő- és energiaigényes, és nem felel meg a klinikai környezet speciális jellegéből fakadó elvárásoknak.

A szomatikus betegek esetében a klinikai és kutatási tapasztalatok azt mutatják, hogy a különböző nonverbális technikák, mint például a vizuális skálák, rajztesztek, 
sok esetben hatékonyabban alkalmazhatók a betegek lelki dimenzióinak vizsgálatára, mint a hagyományos papírceruza alapú pszichológiai tesztek. Egyrészt ugyanis nehezen verbalizáló betegek esetében is jól alkalmazhatók, másrészt kevesebb energiaráfordítást igényelnek, és mindezek mellett lehetőséget nyújtanak a nem tudatos érzések, gondolatok feltárására is [11-14].

Tapasztalataink alapján a súlyos állapotú szomatikus betegekkel végzett egészségpszichológiai tevékenység során a kvantitatív adatokat nyújtó mérőeszközök alkalmazásán túl olyan komplex mérőeszközre van szükség, melynek segítségével viszonylag kevés idő- és energiaráfordítással széles körű információhoz juthatunk a beteg pszichés állapotáról és a betegség szubjektív megéléséről. Korábbi vizsgálataink alapján a Büchi és Sensky által 1998-ban kidolgozott és a klinikai gyakorlatban nemzetközileg alkalmazott PRISM (Pictorial Representations of Illness and Self Measure) nonverbális teszt általunk kifejlesztett rajztesztverziója (PRISM-D teszt) jól alkalmazható a páciensek betegséggel összefüggő reprezentációinak mérésére [15-18]. Az eredeti PRISM teszt olyan egyszerü vizuális technika, mely egy dimenziót: a betegség következtében megélt szenvedés mértékét tárja fel [19]. A teszt további módosított verziói képet nyújtanak a betegségpercepcióról (PRISM-RI teszt) [20], illetve a betegség és bizonyos tényezők (például betegség és család, munka, hobbi stb.) viszonyáról (PRISM+ teszt) [21, 22].

Az általunk kifejlesztett PRISM-D rajzteszt a korábbi PRISM tesztek előnyeit megtartva, a tesztek által vizsgált dimenziók differenciáltabb mérését teszi lehetővé $[23,24]$. A rajzteszttel részletesen tovább vizsgálható a betegségnek a páciens életébe való ágyazottsága, a személy aktuális életterének résztvevői és a gyógyulást potenciálisan segítő, illetve gátló tényezők. A PRISM-D teszt, utótesztjével kiegészítve, képes komplex képet nyújtani a betegségnek a személyre gyakorolt szubjektív hatásáról és a betegség egyéni értelmezéséről. Korábbi tapasztalataink alapján a módszer további előnye, hogy a páciens aktív részvételét kívánja a tesztfelvétel során, serkenti a kommunikációt, és alkalmas a terápiás folyamat alatti információgyưjtésre és utánkövetésre [18].

Jelen tanulmányunk célja annak vizsgálata volt, hogy a PRISM-D rajzteszt, valamint az ehhez kapcsolódó utóteszt hogyan alkalmazható a klinikai gyakorlatban, súlyos fekvő betegek esetében. Vizsgálatunk során ismertetni kívánjuk, hogy a PRISM-D teszt segítségével milyen módokon mérhetők a betegséggel összefüggő érzelmi és kognitív reprezentációk, kitérve a rajzteszten és az annak utótesztjén nyerhető kvantitatív és kvalitatív adatok elemzési lehetőségeire. További célunk az utóteszt hasznosságának vizsgálata, az ebből nyerhető információk komplexitásának demonstrálása, valamint az utóteszten nyerhető adatok elemzési lehetőségeinek bemutatása aktív kórházi kezelés alatt álló daganatos betegpopuláció példáján keresztül.

\section{1. melléklet | PRISM-D-instrukció vizsgálatvezetők számára}

Kedves Hölgyem/Uram!

Szeretnénk jobban megérteni, hogy betegsége hogyan hat a jelenlegi életére. Itt egy fehér papir. (A vizsgált személyeknek úgy kell odaadnia a lapot, hogy a sárga kör az ő perspektívájából jobbra lent legyen.) Képzelje el, hogy ez a lap az életterét jelenti, ez a sárga kör pedig Önt szimbolizálja. Most arra kérem, hogy ezzel a piros filccel rajzolja le betegségét, ugyanúgy egy koronggal/körrel szimbolizálva azt, oda, ahová a leginkább el tudja helyezni Önmagáboz képest. (Piros filcet adok a kezébe, lerajzolja, elveszem tőle, megköszönöm.) Elakadás esetén további instrukció, ha szükséges: Gondolkodjon el rajta, mennyire befolyásolja életét a betegség, mennyire érzi nehéznek a tüneteit.

Most arra kérem, hogy rajzolja le minden olyan fontos területét az életének, ami eszébe jut (ha rákérdez, hogy mire is gondolok, akkor megjegyzem: például család, munka, hobbi, bármi, ami különös jelentőséggel bír az Ön számára) - ezek a szinek állnak rendelkezésére. Arra kérem, hogy ugyanúgy kör vagy korong alakjában jelenitse meg az Ön számára fontos tényezőket.

Elakadás esetén további instrukció: Gondolkodjon $\mathrm{el}$, mi az, ami még fontos Önnek, és eddig nem rajzolta le. Mi hiányzik még erről a képröl?

Utóteszt: Ez a kör mit jelez az Ön életében?

Közben felírom a jelölőlapra a színekhez a sorszámot és azok jelentését (utóteszt), illetve a tapasztalt különleges reakciókat (dünnyögés, elakadás stb.). Jelöljük azt is, ha kiszínezte a kört: a szín mellett zárójelben egy nagy $\mathbf{S z}$-szel, tehát „piros $(\mathrm{Sz})$ ”. Továbbá Á jel, ha átfed a sárgával, és $\mathbf{H}$ betú, ha hozzáér a sárgához.

A jelek a szín oszlopban:

Sz = beszínezett kör; Á = átfed a sárgával; $\mathrm{H}$ = hozzáér a sárgához

\section{Módszer}

\section{A résztvevoók és a vizsgálat körülményei}

A vizsgálatban 150 fő, kórházi kezelés alatt álló daganatos beteg vett részt. Az alábbi daganattípusban szenvedő személyek vettek részt a vizsgálatban: emlötumoros, gyomor-bél rendszeri daganatos, vérképző szervi daganatos, melanoma malignumos, méhnyakrákos, hererákos és tüdődaganatos betegek. A betegek $81,3 \%$-a nő, 18,7\%-a férfi volt. Az átlagéletkor 56 év volt (SD = $13,68)$.

$\mathrm{Az}$ adatfelvételt pszichológus, illetve viselkedéselemző szakemberek végezték a Szegedi Tudományegyetem Szent-Györgyi Albert Klinikai Központjában, a Békés Megyei Központi Kórház Pándy Kálmán Tagkórházában, valamint a budapesti Országos Onkológiai Intézetben. Az adatfelvétel időtartama körülbelül 15 perc volt.

\section{Méröeszköz}

A PRISM-D teszt a PRISM teszt [19] általunk korábban kifejlesztett rajztesztváltozata [18], melynek esetében egy A/4-es fehér lapon kell a személynek megjelenítenie 
\begin{tabular}{l|l} 
2. melléklet & PRISM-D tesztfelvételi adatlap
\end{tabular}

Nem:

Kor:

Diagnózis:

Osztály:

A tesztfelvétel dátuma:

Felvette:

\begin{tabular}{|c|c|c|c|c|c|c|}
\hline Sorrend & Szín & Méret & Távolság & Jelentés & Különleges reakció & Utóteszt \\
\hline 1. & $\begin{array}{l}\text { Piros } \\
\text { SZ-H-Á }\end{array}$ & $\begin{array}{l}\mathrm{r}=\longleftarrow \mathrm{cm} \\
\mathrm{T}=\longleftarrow \mathrm{cm}^{2}\end{array}$ & $\mathrm{~s}=\ldots \mathrm{cm}$ & Betegség & & \\
\hline 2. & SZ-H-Á & $\begin{array}{l}\mathrm{r}=\mathrm{cm} \\
\mathrm{T}=\longleftarrow \mathrm{cm}^{2}\end{array}$ & $\mathrm{~s}=\ldots \mathrm{cm}$ & & & \\
\hline 3. & SZ-H-Á & $\begin{array}{l}\mathrm{r}=\longleftarrow \mathrm{cm} \\
\mathrm{T}=\longleftarrow \mathrm{cm}^{2}\end{array}$ & $\mathrm{~s}=\ldots \mathrm{cm}$ & & & \\
\hline 4. & SZ-H-Á & $\begin{array}{l}\mathrm{r}=\longleftarrow \mathrm{cm} \\
\mathrm{T}=\longleftarrow \mathrm{cm}\end{array}$ & $\mathrm{s}=\ldots \mathrm{cm}$ & & & \\
\hline 5. & SZ-H-Á & $\begin{array}{l}\mathrm{r}=\longleftarrow \mathrm{cm} \\
\mathrm{T}=\longleftarrow \mathrm{cm}^{2}\end{array}$ & $\mathrm{~s}=\_\mathrm{cm}$ & & & \\
\hline 6. & SZ-H-Á & $\begin{array}{l}\mathrm{r}=\mathrm{cm} \\
\mathrm{T}=\longleftarrow \mathrm{cm}^{2}\end{array}$ & $\mathrm{~s}=\ldots \mathrm{cm}$ & & & \\
\hline 7. & SZ-H-Á & $\begin{array}{l}\mathrm{r}=\mathrm{cm} \\
\mathrm{T}=\longleftarrow \mathrm{cm}^{2}\end{array}$ & $\mathrm{~s}=\ldots \mathrm{cm}$ & & & \\
\hline 8. & SZ-H-Á & $\begin{array}{l}\mathrm{r}=\longleftarrow \mathrm{cm} \\
\mathrm{T}=\longleftarrow \mathrm{cm}^{2}\end{array}$ & $\mathrm{~s}=\ldots \mathrm{cm}$ & & & \\
\hline 9. & SZ-H-Á & $\begin{array}{l}\mathrm{r}=\ldots \mathrm{cm} \\
\mathrm{T}=\longleftarrow \mathrm{cm}^{2}\end{array}$ & $\mathrm{~s}=\ldots \mathrm{cm}$ & & & \\
\hline 10. & SZ-H-Á & 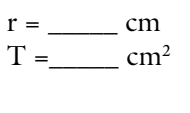 & $\mathrm{s}=\ldots \mathrm{cm}$ & & & \\
\hline 11. & SZ-H-Á & $\begin{array}{l}\mathrm{r}=\longleftarrow \mathrm{cm} \\
\mathrm{T}=\_\mathrm{cm}^{2}\end{array}$ & $\mathrm{~s}=\ldots \mathrm{cm}$ & & & \\
\hline 12. & SZ-H-Á & $\begin{array}{l}\mathrm{r}=\longleftarrow \mathrm{cm} \\
\mathrm{T}=\longleftarrow \mathrm{cm}^{2}\end{array}$ & $\mathrm{~s}=\ldots \quad \mathrm{cm}$ & & & \\
\hline 13. & SZ-H-Á & $\begin{array}{l}\mathrm{r}=\mathrm{cm} \\
\mathrm{T}=\mathrm{cm}^{2}\end{array}$ & $\mathrm{~s}=\ldots \mathrm{cm}$ & & & \\
\hline 14. & SZ-H-Á & $\begin{array}{l}\mathrm{r}=\ldots \mathrm{cm} \\
\mathrm{T}=\longleftarrow \mathrm{cm}^{2}\end{array}$ & $\mathrm{~s}=\_\mathrm{cm}$ & & & \\
\hline 15. & SZ-H-Á & $\begin{array}{l}\mathrm{r}=\ldots \mathrm{cm} \\
\mathrm{T}=\longleftarrow \mathrm{cm}^{2}\end{array}$ & $\mathrm{~s}=\ldots \mathrm{cm}$ & & & \\
\hline
\end{tabular}

A jelek a szín oszlopban:

Sz = beszínezett kör; Á = átfed a sárgával; $\mathrm{H}$ = hozzáér a sárgához

r = a berajzolt kör sugara; $s$ = a berajzolt kör középpontja és az Ént szimbolizáló kör középpontja között mért távolság; T = a berajzolt kör területe 
a betegségét egy általa piros filctollal rajzolt kör segítségével. A teszten a fehér lap a személy aktuális életterét szimbolizálja, a lap jobb alsó sarkában pedig egy előre nyomtatott, $7 \mathrm{~cm}$ átmérőjü sárga kör található, mely a személy Énjét szimbolizálja. Az instrukció szerint (1. melléklet) a vizsgálatban részt vevő személy elsőként a betegségét rajzolja be a tesztlapra, szabadon, méret és elhelyezkedésbeli megkötés nélkül [18]. A korábbi verziók elemzési metodikáját megtartva, a PRISM-D teszten az Ént és a betegséget szimbolizáló kör középpontjai közötti távolság, az úgynevezett Self-Illness Separation (SIS) [19] utal a betegség okozta szubjektív szenvedés mértékére. A berajzolt betegség mérete pedig az úgynevezett Illness Perception Measure (IPM) [20], mely a betegségpercepcióra utal.

A PRISM-D teszt második részében a vizsgálatban részt vevő személyek tetszőleges színü filctollak segítségével megjeleníthetik az életterükben aktuálisan jelen lévő, számukra fontos tényezőket. Ez alapján képet kaphatunk a személy életterének komplexitásáról, a gyógyulásban szerepet játszó protektív és hátráltató tényezőkrôl.

A tesz harmadik részében, az utóteszt során, a vizsgálatvezető külön erre szolgáló adatlapon feljegyzi a berajzolt körök jelentését. Továbbá feljegyzi az esetlegesen előforduló különleges reakciókat (sírás, zavartság, düh kifejezése stb.). Az egyes berajzolt körökre vonatkozóan megkérdezi, hogy mit jelent a vizsgálatban részt vevó személy számára az adott tényező. A válaszokat az adatlapon rögzíti (2. melléklet).

\section{Adatelemzés}

Az adatelemzés során egyrészt az Én-betegség távolság (Self-Illness Separation, SIS) került kiszámításra, melyet az Ént és a betegséget szimbolizáló körök középpontjai

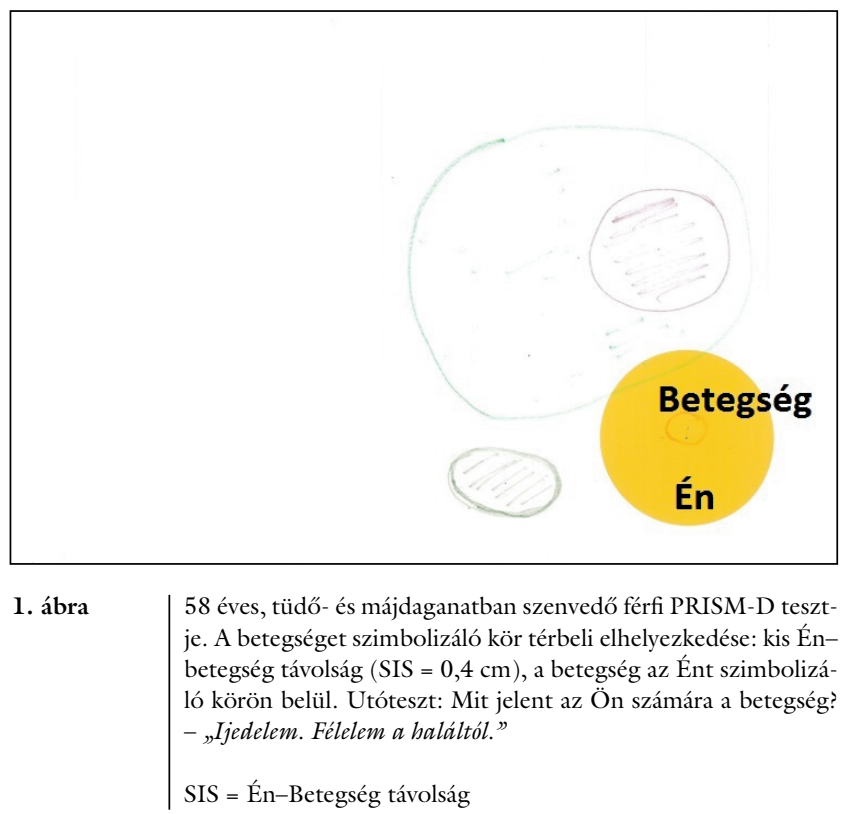

között mérünk. Másrészt kiszámoltuk a berajzolt, betegséget szimbolizáló kör területét (Illness Perception Measure, IPM). Ezt követte az értékek leíró statisztikai elemzése (átlag, szórás), valamint a berajzolt körök kategorizálása. A betegségen kívüli egyéb megjelenített körök (Gyógyulás, Egészség) tekintetében válaszmegoszlások kerültek meghatározásra (százalék).

Az utóteszten nyert szöveges adatokat a tartalomelemzés módszerével vizsgáltuk. A válaszokat jelentéstartalmuk alapján kategorizáltuk. A kategóriákat két független kódoló hozta létre. Az adatelemzés során a kategóriák előfordulási gyakoriságát százalékos formában tüntettük fel. Az utótesztek kvalitatív elemzését a jelen vizsgálatban a Betegség, Gyógyulás és Egészség körök jellemzői szerint végeztük.

\section{Eredmények}

\section{$A$ betegségre adott reakció}

\section{A betegséget szimbolizáló kör térbeli elhelyezkedése alapján}

A betegség Éntől való térbeli elhelyezkedése az Én-betegség viszonyra utal. A térbeli pozíciót tekintve a vizsgálatban részt vevő személyek 18,8\%-a jelenítette meg a betegséget az Énen belül, 6,7\%-uk az Énhez hozzáérve, $74,5 \%$-uk pedig az Énen kívül.

Az Ént és a betegséget szimbolizáló körök középpontja közötti távolság (SIS) alapján a minta egészére nézve nagyfokú betegségtől való szenvedés jellemző $(M=10,62 ; S D=8,13)$. A magas szórásérték az eredmények nagyfokú heterogenitására, a megélés egyéni változatosságára utal. A legkisebb felvett érték $0 \mathrm{~cm}$, a legnagyobb 28,9 volt. A teszten megjelenített, betegséget szimbolizáló körök térbeli pozícióját szemlélteti az 1. és a 2. ábra.

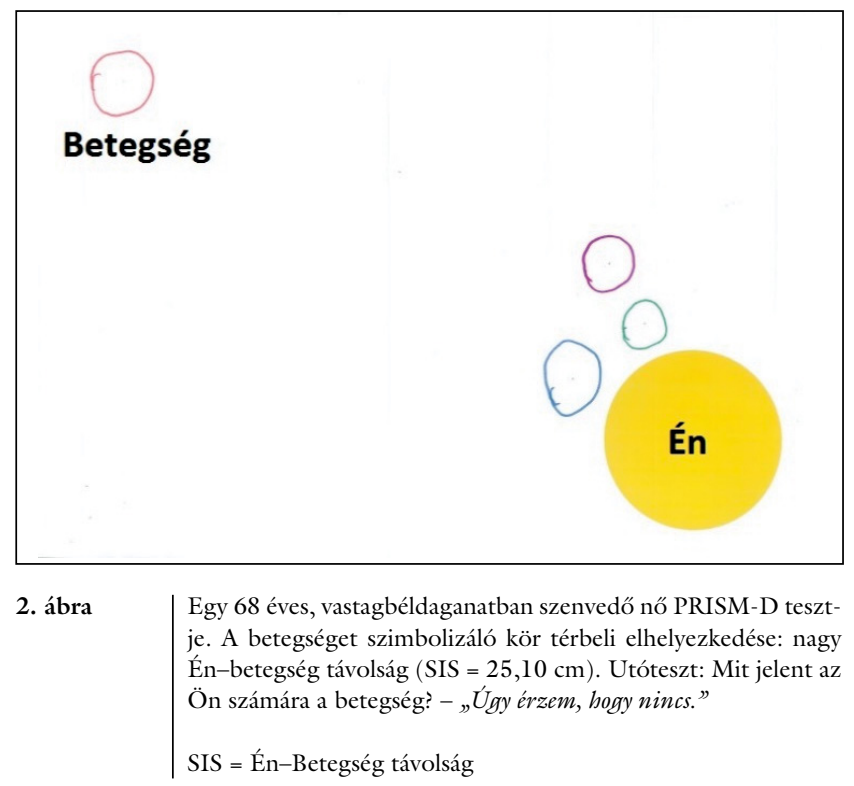


A PRISM-D-utóteszt Betegségre vonatkozó válaszainak kvalitatív elemzése alapján a betegségre adott reakciók válaszkategóriáinak \%-os megoszlása, illetve példamondatok

\begin{tabular}{lll}
\hline Kategória & $\begin{array}{l}\text { Előfordulás } \\
\text { gyakorisága (\%) }\end{array}$ & Példa \\
\hline $\begin{array}{l}\text { Negatív érzelem, } \\
\text { distressz, katasztrofizálás }\end{array}$ & 27,3 & "Lelkileg összetört.” \\
\hline $\begin{array}{l}\text { Tagadás, hárítás, Éntől } \\
\text { való távolítás }\end{array}$ & 14 & $\begin{array}{l}\text { „Úgy érzem, hogy } \\
\text { nincs”, „Mintha ez } \\
\text { velem nem történt } \\
\text { volna meg.” }\end{array}$ \\
\hline $\begin{array}{l}\text { Megküzdés, problémafó- } \\
\text { kuszú és megoldáskereső } \\
\text { hozzállás }\end{array}$ & 16 & $\begin{array}{l}\text { „Leküzdhet”, tehát le } \\
\text { fogom küzdeni, egy } \\
\text { leküzdhetó gond.” }\end{array}$ \\
\hline $\begin{array}{l}\text { Énbe való integrálás } \\
4\end{array}$ & $\begin{array}{l}\text { "Ez most nagyon } \\
\text { meghatározza az } \\
\text { életem, nagyon bennem } \\
\text { van.” }\end{array}$ \\
\hline Elfogadás & 2,7 & $\begin{array}{l}\text { Eleinte rossz volt, } \\
\text { most elfogadtam, } \\
\text { együtt élek vele.” }\end{array}$ \\
\hline
\end{tabular}

A teszten a kisebb Én-betegség távolság a szenvedés fokozott megélésére utal, a nagyobb távolság pedig alacsonyabb fokú lelki szenvedést jelez. A vizsgált minta 16\%-ánál volt megfigyelhető szélsőségesen nagy Én-betegség távolság (SIS>20 cm), mely a vizsgálatban részt vevő személyek aktuális szomatikus állapotát figyelembe véve a betegség elhárítására enged következtetni.

\section{A betegséget szimbolizáló körhöz kapcsolódó utóteszt alapján}

A PRISM-D teszt utótesztjének tartalomelemzése során a válaszok $64 \%$-ában találtunk betegségre adott reakcióra utaló tartalmat. A válaszokban a leggyakrabban a negatín érzelmi reakció, a fokozott mértékü distressz, illetve a katasztrofizálás jelent meg (27,3\%). A válaszok 14\%-a utal a betegség tagadására, háritására, az Éntől való távolítására. A betegek 16\%-ánál a betegséggel való megküzdés vagy valamilyen konkrét megküzdéses válaszra utaló tartalom, illetve a betegséghez való problémaorientált hozzáállás került megfogalmazásra. A válaszok 4\%-ában a betegség Énbe való integrálását fogalmazták meg, mely arra utal, hogy a betegség a személy részévé vált. További 2,7\%-ában megjelent a betegség elfogadása (1. táblázat).

\section{A betegséggel kapcsolatos reprezentációk}

\section{A betegséggel kapcsolatos érzelmi reprezentációk}

A betegséget szimbolizáló körhöz kapcsolódó utóteszt válaszainak 43\%-ában kerültek említésre a betegséggel kapcsolatos érzelmi reprezentációk, melyből 40,9\% negatív érzelmi reakcióra utal. A válaszoknak csupán 2,1\%ában került megfogalmazásra pozitív vagy semleges érze- lem a betegséggel kapcsolatban. Az összes utóteszt 11,3\%-ában általánosságban rossz érzést fogalmaztak meg, 8,7\%-ában distresszt, 4,4\%-ában félelmet, 2,7\%ában szomorúságot, 2,7\%-ában meglepetést, 2\%-ában bizonytalanságot. 2\%-nál alacsonyabb gyakorisággal említett érzelmi tartalmak voltak: tehetetlenség, kilátástalanság, lelkiismeret-furdalás, lelki sokk.

\section{Betegségpercepció - A betegséget szimbolizáló kör} mérete alapján

A betegséget szimbolizáló kört a vizsgálatban részt vevők átlagosan kisebbnek jelenítették meg, mint az Ént szimbolizáló kört. A berajzolt betegséget szimbolizáló körök mérete átlagosan $12,75 \mathrm{~cm}^{2}$-es méretű volt (IPM), a nagy szórásérték $(S D=24,57$ ) azonban nagy egyéni változatosságra utal. A legnagyobb méretű kör 254,46

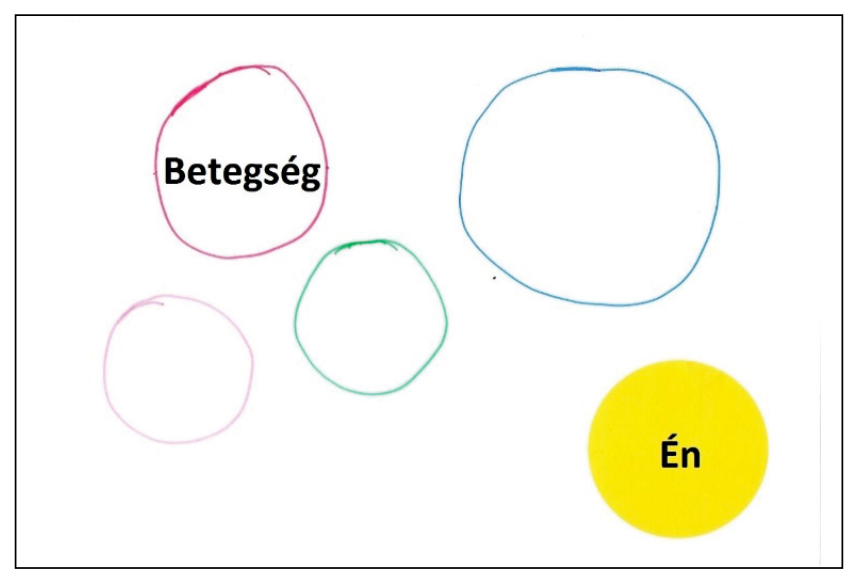

3. ábra

Egy 68 éves, emlőtumorban szenvedő nő PRISM-D tesztje. A betegséget szimbolizáló kör mérete nagy (IPM $=38,47 \mathrm{~cm}^{2}$ ). Utóteszt: Mit jelent az Ön számára a betegség? - „A betegség rosszul érintett.”

IPM = betegségpercepció

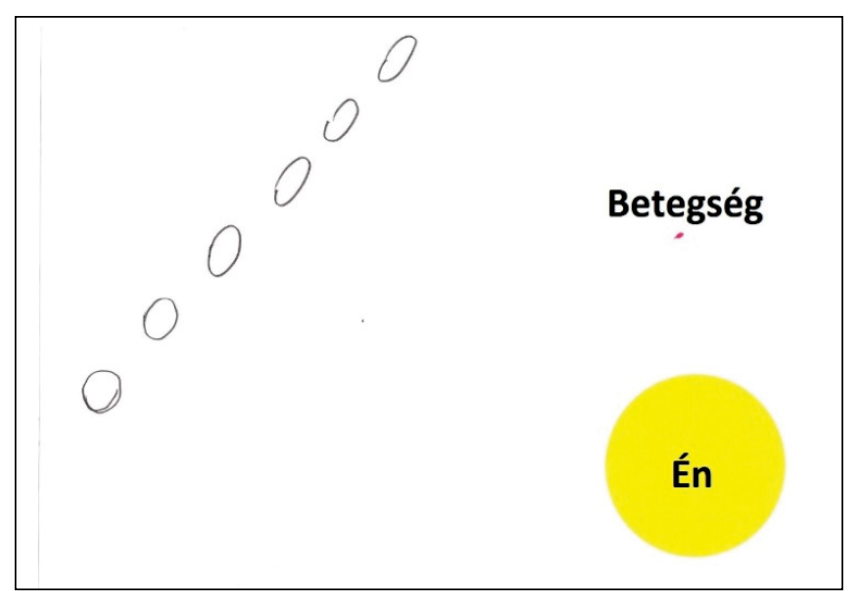

4. ábra

Egy 43 éves, emlőtumorban szenvedő nő PRISM-D tesztje. A betegséget szimbolizáló kör mérete kicsi $\left(\mathrm{IPM}=0,08 \mathrm{~cm}^{2}\right)$. Utóteszt: Mit jelent az Ön számára a betegség? - „Szeretnék túl lenni a betegségen. Gyógyulást.”

IPM = betegségpercepció 
$\mathrm{cm}^{2}$ volt, mely $9 \mathrm{~cm}$ átmérőjü körre utal, a legkisebb pedig $0,01 \mathrm{~cm}^{2}$, ami valójában egy pici pont. A vizsgálatban részt vevők 42\%-a $1 \mathrm{~cm}$ átmérőjünél kisebbnek jelenítette meg a betegségét $\left(3,14 \mathrm{~cm}^{2}\right.$ területü kör).

Összességében a megkérdezettek $88,7 \%$-a jelenítette meg az Énnél kisebbnek a betegségét, 6,7\%-uk a betegséggel közel azonos méretűként. A betegek 4,7\%-ánál azonban a betegség „nagyobb”, mint az Én. Az egyes teszteken megjelenített, betegséget szimbolizáló körök közötti nagyfokú eltéréseket a 3. és a 4. ábra mutatja.

\section{Betegségpercepció - A betegséget szimbolizáló kör- höz kapcsolódó válaszok az utóteszt alapján}

Az utótesztek 36\%-ának esetében találtunk betegségreprezentációra utaló választartalmat. Az ezen szempontból kategorizálható válaszok között a leggyakoribb reprezentáció a betegség jelzésként való interpretálása volt $(31,5 \%)$. A második leggyakoribb kategória a betegség gátként, akadályként való megélése volt $(25,9 \%)$. Gyakori válaszkategória volt továbbá a betegség megoldandó feladatként való interpretálása (18,5\%). A válaszadók $5,55 \%$-a a betegséget a küzdelemmel azonosítja. A betegség lefolyása szempontjából kedvezőtlenebb válaszkategóriák a betegség veszteségként $(7,4 \%)$, csapásként $(5,55 \%)$ vagy személyes kudarcként $(5,55 \%)$ való interpretálása (2. táblázat).

A betegség szimbólumként való megjelenítése során a betegséget „derült égből villámcsapásként”, „pofonként” fogalmazták meg.

2. táblázat |A PRISM-D utótesztjének Betegségre vonatkozó kérdésében megfogalmazott betegséginterpretáció-kategóriák típusai, százalékos megoszlásuk és példamondatok

\begin{tabular}{|c|c|c|}
\hline Kategória & $\begin{array}{l}\text { Előfordulás } \\
\text { gyakorisága } \\
(\%)\end{array}$ & Példa \\
\hline $\begin{array}{l}\text { Jelzés, } \\
\text { változás }\end{array}$ & 31,50 & $\begin{array}{l}\text { „Rádöbbentett arra, hogy mit } \\
\text { rontottam el. Új irányban kell } \\
\text { haladnom.” } \\
\text { „Szükséges rossz, amivel megváltozta- } \\
\text { tom az életem és a gondolkodásom.” }\end{array}$ \\
\hline $\begin{array}{l}\text { Gát, akadály, } \\
\text { teher }\end{array}$ & 25,90 & $\begin{array}{l}\text { „Elég nagy teher. Ezt kaptam a sorstól, } \\
\text { el kell viselni.” } \\
\text { „Hátráltató tényező.” }\end{array}$ \\
\hline Feladat & 18,50 & $\begin{array}{l}\text { „Probléma, amit meg kell oldani.” } \\
\text { „Megoldandó feladat.” }\end{array}$ \\
\hline Veszteség & 7,40 & $\begin{array}{l}\text { „Elvesztegetett idő.” } \\
\text { „Mindent háttérbe szorít.” } \\
\text { „Karrier kettétörése.” } \\
\text { „Sok mindenben korlátoz, felborítja az } \\
\text { életem.” }\end{array}$ \\
\hline Csapás & 5,55 & $\begin{array}{l}\text { „Pofon, egészségesen éltem az életem, } \\
\text { derült égból villámcsapás.” }\end{array}$ \\
\hline Küzdelem & 5,55 & „Küzdeni akarok, amíg lehet.” \\
\hline Kudarc & 5,55 & $\begin{array}{l}\text { „Kudarc, mindig vigyáztam az } \\
\text { egészségemre.” }\end{array}$ \\
\hline
\end{tabular}

\section{A betegség kimenetelével kapcsolatos reprezentációk}

A betegséget szimbolizáló körhöz kapcsolódó utóteszt válaszainak 16\%-ában találhatunk a betegség kimenetelére utaló választartalmakat. A betegség kimenetelével kapcsolatos válaszok többsége $(91,87 \%)$ a betegség pozitív irányú változásával kapcsolatos gondolatokat tartalmazott (gyógyulásba vetett hit, pozitív jövőbeli változások). Csupán az ilyen tartalmú válaszok 8,13\%-ában, az összes válasz 1,3\%-ában találhatunk negatív kimenetellel kapcsolatos választartalmakat (a betegség rosszabbodása, halál és az ezektől való félelem).

A megkérdezettek 13,4\%-a jelenítette meg a PRISMD teszten a gyógyulását egy külön körrel. Az utótesztre adott válaszok („Mit jelent az Ön számára a gyógyulás?”) a gyógyulás fontosságára és az azzal kapcsolatos hitre, vágyra és célra vonatkoztak. A vizsgálatban részt vevő személyek 14,6\%-a tüntette fel a teszten külön körrel az egészségét. Az utóteszt válaszaiban az alábbi tartalmak jelentek meg („Mit jelent az Ön számára az egészség?”): az egészség fontosságának hangsúlyozása; az egészség mint élet; az egészség mint boldogság; az egészség mint elérendő cél (3. táblázat).

\section{Megbeszélés}

Vizsgálatunk során a PRISM-D teszt és utótesztje klinikai alkalmazhatóságának bemutatását tüztük ki célul. Eredményeink szerint a méróeszköz részletes és komplex, ugyanakkor könnyen és gyorsan alkalmazható klinikai környezetben. A teszt egyaránt nyújt kvantitatív és kvalitatív információt a betegséggel összefüggő reprezentációkról és a betegségre adott reakciókról. A PRISM-D

\section{3. táblázat | A PRISM-D teszten Gyógyulást, illetve Egészséget szimbolizáló körök megjelenítési aránya (\%), illetve a fentiekhez kapcsolódó utótesztekre adott válaszok jelentéskategóriái példamondatok- kal}

\begin{tabular}{lll}
\hline & Gyógyulás & \\
\hline Megjelenítette (\%) & 13,4 & \\
\hline Jelentése & Érték & „A legfontosabb az életemben.” \\
& Cél & „Ez a legfontosabb cél, hogy \\
& helyreálljon minden.” \\
& Hit & „Hiszek benne, de nehéz.” \\
& Vágy & „Szeretnék gyógyulni.” \\
& Csoda & „Egy csoda lenne.” \\
\hline Egészség & \\
\hline Megjelenítette (\%) & 14,6 & \\
\hline Eelentése & Érték & „A legfontosabb, akkor jövünk \\
& Élet & "Az életemet.” \\
& Boldogság & „Boldogságot.” \\
& Cél & „Elérendő cél.”
\end{tabular}


rajzteszt és annak utótesztje a teszt korábbi verzióihoz képest a szubjektív reprezentációk differenciált feltárását teszi lehetővé. A teszten megjelenített, betegséget szimbolizáló kör térbeli elhelyezkedésének és méretének értelmezésén túl az utóteszt segítségével részletes, több szempontból elemezhető kvalitatív információt kaphatunk.

A teszten megjelenített, betegséget szimbolizáló kör térbeli elhelyezkedésének kvantitatív értékelésével, az Én-betegség távolság (SIS) elemzésével feltárható a betegség nyomán fellépő szenvedés mértéke csakúgy, mint az eredeti PRISM teszten [19]. Eredményeink szerint a teszten megjelenített betegség Éntől való távolsága alapján a megkérdezett személyekre általánosságban a betegségtől való nagymértékű szenvedés jellemző. A SIS-érték nagymértékű szórása azonban arra utal, hogy a vizsgált betegek által megélt szenvedés mértéke nagy egyéni változatosságot mutat.

A betegséget szimbolizáló körnek az Ént szimbolizáló körhöz képest a tesztlapon elfoglalt térbeli pozíciója utalhat a betegség tagadására vagy távolítására nagy ÉnBetegség távolság esetében (jellemzően olyan esetekben, amikor a betegséget szimbolizáló kör az Éntől a lap lehető legtávolabbi pontján helyezkedik el, a bal felső sarokban). A térbeli pozíció értelmezésekor azonban mindig figyelembe kell venni a páciens aktuális fizikális állapotát, ugyanis a nagy távolság az Én és a betegség között gyógyult állapotban vagy javulás esetén adaptív válasznak tekinthető. Súlyos betegség akut szakaszában azonban az Éntől való távolításként, szélsőségesen nagy távolság esetében pedig akár tagadásként értelmezendő, mely, amennyiben tartósan fennálló reakcióként van jelen, gátolhatja a betegséggel való sikeres megküzdést. A jelen betegpopuláció esetében, mivel a betegek az adatfelvétel időpontjában súlyos krónikus betegség aktív kezelése alatt álltak, a betegség ilyen típusú ábrázolása a betegség elhárításaként értelmezendő, mely a vizsgálatban részt vevők 16\%-ánál volt megfigyelhető.

A betegség és az Én egymáshoz viszonyított térbeli elhelyezkedése továbbá jelezheti a betegség Énbe való beépítését, integrációját is abban az esetben, ha a betegséget a páciens az Ént szimbolizáló körön belül vagy azzal átfedésben jeleníti meg. Ilyen esetben a személy a betegséget önmaga részeként éli meg. Ez a típusú megjelenítés a megkérdezett betegek 18,8\%-ánál volt megfigyelhető, további 6,7\%-uk pedig a betegséget az Énhez hozzáérve jelenítette meg, ami szintén jelzi a betegség önmagához való közelségét.

A teszten berajzolt, betegséget szimbolizáló kör méretéből következtetni tudunk a betegség szubjektíve megélt „nagyságára”, mely a teszt korábbi verziói alapján [20] a betegségpercepcióra utal. Eredményeink szerint a betegség szubjektíve megélt mérete nagyfokú egyéni eltérést mutat a vizsgált mintán belül, ugyanis a legkisebb megjelenített kör $0,01 \mathrm{~cm}$ átmérőjü, a legnagyobb $9 \mathrm{~cm}$ átmérőjű volt. A berajzolt betegség mérete a betegséggel való megküzdés szempontjából fontos információt nyújt.
A nagyon kicsi méret azt szimbolizálja, hogy a páciens a betegségét kicsinek éli meg, ami súlyos szomatikus állapot esetében a betegség bagatellizálására is utalhat. A nagyméretúnek megjelenített betegség pedig utal arra, hogy a betegség uralja a személy életterét, és kérdéses lehet, hogy rendelkezésre áll-e a személy számára annyi erőforrás, melynek segítségével sikeresen megküzdhet a betegséggel és az abból adódó kihívásokkal.

Hasznos információt nyújthat annak értelmezése, hogy milyen a betegséget szimbolizáló körnek az Ént szimbolizáló körhöz viszonyított mérete, mely megmutatja, hogy a beteg a betegségét szubjektíve önmagához képest „mekkorának”, milyen súlyosnak, milyen jelentősnek éli meg. Az Énnél nagyobb kör jelzi, hogy a páciens a betegségét önmagánál „nagyobb” ágensként szemléli, melynek „legyőzése” önerőből nehezebb lehet, így a megküzdés szempontjából kedvezőtlenebb kimenetelre utal. Ez a típusú ábrázolás a vizsgálatban részt vevő személyek 4,6\%-ánál volt megfigyelhető. 6,6\%-uk az Énnel közel azonos méretünek jelenítette meg a betegségét, 88,8\%-uk pedig kisebbnek.

Eredményeink szerint a fenti elemzéseket jól kiegészítik az utótesztre adott válaszok. Egyrészt megerősítik a betegséget szimbolizáló kör méretéből és térbeli elhelyezkedéséből nyert eredményeket, másrészt annál differenciáltabb információt is nyújtanak a szakember számára. A betegségre vonatkozó utótesztben, a „Mit jelent az Ön számára a betegség?” kérdésre megfogalmazott válaszok nagy egyéni változatosságot mutatnak, ami utal arra, hogy a módszer alkalmas az egyéni reakciók, érzések és értelmezések feltárására. A válaszok többnyire komplexek, a betegséggel és annak megélésével kapcsolatban többféle információt is tartalmaznak. A tartalomelemzés eredményei szerint a válaszok több kategória mentén is jól elemezhetők.

A betegséget szimbolizáló körhöz kapcsolódó utóteszt válaszainak $64 \%$-ában találhatunk a betegségre adott reakciókra utaló választartalmat, úgymint negatív érzések megélése/érzelmi reakció, tagadás/elhárítás, a betegséghez való problémaorientált hozzáállás, a betegség elfogadása és a betegség Énbe való integrációja. A válaszok $43 \%$-ában találhatók a betegséggel kapcsolatos érzésekre vonatkozó tartalmak, melyek 98\%-a negatív érzelmi reprezentációt tartalmaz. A leggyakrabban említett érzelmi reprezentációk a distressz, a félelem, a szomorúság, a meglepetés, a bizonytalanság és az általánosan rossz érzés voltak.

A válaszok 36\%-ában találunk a betegségreprezentációra, a betegség szubjektív értelmezésére, interpretálására utaló válaszokat. A vizsgált betegek esetében a betegség jelzésként, feladatként, akadályként, veszteségként, csapásként, küzdelemként, kudarcként való megélése jelent meg. A válaszok relatíve kevés, csupán 16\%-a utalt a betegség kimenetelére, mely válaszok többsége a betegség pozitív kimenetelével kapcsolatos hitre, vágyra utalt. A betegség kimenetelével kapcsolatos nézetekre utalnak továbbá az opcionálisan berajzolt, gyógyulást vagy 
egészséget szimbolizáló körök. A gyógyulást a betegek 13,4\%-a, az egészséget 14,6\%-a jelenítette meg külön körrel, ami ezeknél a betegeknél utal ezen tényezők szubjektív fontosságára.

\section{Következtetések}

Elmondható, hogy eredményeink szerint a PRISM-D teszt és annak utótesztje alkalmas a betegséggel kapcsolatos egyéni reakciók és kogníciók feltárására. Az eljárás előnye, hogy a tesztfelvétel gyors, egyszerü, ennek ellenére rendkívül komplex képet nyújt a betegség egyénre gyakorolt szubjektív hatásáról. A PRISM-D rajzteszt az eredeti PRISM teszt előnyeit megtartva, azt továbbfejlesztve differenciált képet nyújt súlyos betegeknek a betegségtől való szenvedésérôl és betegségpercepciójáról. A vizuális eszköz egyszerü adatfelvételt tesz lehetővé klinikai környezetben, súlyos fekvő betegek esetében. A teszt nonverbális jellege miatt akár verbálisan nehezen hozzáférhető betegek esetében is alkalmazható.

Jelen vizsgálatunk a PRISM-D utótesztjének hasznosságára hívja fel a figyelmet. Eredményeink szerint az utótesztre adott válaszok jól kiegészítik a rajzteszt során nyert információkat, ezáltal a betegséggel kapcsolatos érzelmi és kognitív reprezentációk komplex feltárását teszik lehetővé.

A PRISM-D teszt és annak utótesztje jól alkalmazható a klinikai egészségpszichológiai tevékenység során szürőtesztként, a klinikai szempontból tovább vizsgálandó reakciók detektálására is. Ugyanakkor alkalmas az egyénvagy csoportmunka során a terápiás folyamat részét képező feltáró eszközként a terápiás folyamat megtervezésére, illetve az állapotváltozás nyomon követésére. A kvantitatív adatok elemzése pedig lehetővé teszi a nagy mintán végzett összehasonlító vizsgálatok kivitelezését.

Anyagi támogatás: A közlemény megírása, illetve a kapcsolódó kutatómunka anyagi támogatásban nem részesült.

Szerzői munkamegosztás: S. Z.: A kutatás megtervezése, adatgyüjtés, az adatok statisztikai értelmezése, a publikáció megírása. Cs. M.: A kutatási terv kidolgozása, az eredmények értelmezése, a kézirat megírásában nyújtott segítség. A cikk végleges változatát mindkét szerző elolvasta és jóváhagyta.

Érdekeltségek: A szerzőknek nincsenek érdekeltségeik.

\section{Köszönetnyilvánítás}

Szeretnénk köszönetet mondani a kutatást segítő kollégáinknak, $D r$. Látos Melindának és Dr. Kovács Péternek.

\section{Irodalom}

[1] Hagger M, Orbell S. A meta-analytic review of the commonsense model of illness representations. Psychol Health 2003; 18 : 141-184.

[2] Anagnostopoulos F, Spanea E. Assessing illness representations of breast cancer. A comparison of patients with healthy and benign controls. J Psychosom Res. 2005; 58: 327-334.

[3] Petrie KJ, Jago LA, Devcich DA. A role of illness perceptions in patients with medical conditions. Curr Opin Psychiatry 2007; 20: 163-167.

[4] Rohánszky M, Berényi K, Fridrik D, et al. Effectiveness of mindfulness-based cancer recovery (MBCR) program among Hungarian cancer patients. [Éber, tudatos figyelemre épülö, a rákbetegséggel való megküzdést segítő program (MBCR) hatásvizsgálata magyar rákbetegek körében.] Orv Hetil. 2017; 158: 1293-1301. [Hungarian]

[5] Muszbek K, Gaal I. Pitfalls within the cancer-related doctor-patient communication. [Az orvos-beteg kommunikáció csapdái daganatos betegség esetén.] Orv Hetil. 2016; 157: 649-653. [Hungarian]

[6] Kreitler S. Denial in cancer patients. Psychosocial issues. Cancer Invest. 1999; 17: 514-534.

[7] McGregor BA, Antoni MH. Psychological intervention and health outcomes among women treated for breast cancer: a review of stress pathways and biological mediators. Brain Behav Immun. 2009; 23: 159-166.

[8] Weinman J, Petrie KJ. Illness percepctions: a new paradigm for psychosomatics? J Psychosom Res. 1997; 42: 113-116.

[9] Büssing A, Fischer J. Interpretation of illness in cancer survivors is associated with health-related variables and adaptive coping styles. BMC Women's Health 2009; 9: 2.

[10] Leventhal H, Leventhal EA, Cameron L. Representations, procedures, and affect in illness self-regulation: a perceptual-cognitive model. In: Baum A, Revenson TA, Singer JE. (eds.) Handbook of Health Psychology. Erlbaum, Mahwah, NJ, 2001; pp. 19-47.

[11] de C Williams AC, Davies HT, Chadury Y. Simple pain rating scales hide complex idiosyncratic meanings. Pain 2000; 85: 457463.

[12] Houts PS, Witmer JT, Egeth HE, et al. Using pictographs to enhance recall of spoken medical instructions II. Patient Educ Couns. 2001; 43: 231-242.

[13] Broadbent E, Ellis CJ, Gamble G, et al. Changes in patient drawings of the heart identify slow recovery after myocardial infarction. Psychosom Med. 2006; 68: 910-913.

[14] Látos M, Barabás K, Lázár G, et al. Mental representations of the new organ and posttransplant patients' anxiety as related to kidney function. Transplant Proc. 2012; 44: 2143-2146.

[15] Havancsák R, Kovács P, Látos M, et al. Application of the PRISM drawing test to explore the illness representations and the factors facilitating coping of hospital inpatients: first Hungarian observations. In: Vargha A. (ed.) The human face of science: XXIth National Scientific Congress of the Hungarian Psychological Association: Abstract book. [A PRISM rajzteszt alkalmazása kórházi betegek reprezentációinak és a megküzdést segítő tényezők feltárására: Első hazai tapasztalatok. In: Vargha A. (szerk.) A tudomány emberi arca: A Magyar Pszichológiai Társaság XXI. Országos Tudományos Nagygyúlése: Kivonatkötet.] Magyar Pszichológiai Társaság, Szombathely, 2012; p. 311. [Hungarian]

[16] Havancsák R, Kovács P, Látos M, et al. Observations of the first Hungarian application of the PRISM-D drawing test for hospital inpatients with cancer. In: Barabás K, Kapocsi E, Pikó B. (eds.) XIIth Behavioral Sciences Days: Program and abstracts. [A PRISM 
nonverbális teszt első hazai alkalmazásának tapasztalatai kórházi osztályokon fekvő daganatos betegekkel. In: Barabás K, Kapocsi E, Pikó B. (szerk.) XII. Magatartástudományi Napok: Programfüzet és absztraktok kivonata.] JATEPress Kiadó, Szeged, 2012; p. 72. [Hungarian]

[17] Pócza-Véger P, Havancsák R, Látos M, et al. Visualization of illness representations of hospital patients by the use of the PRISMD drawing test. In: Kővágó P, Vass Z, Vargha A. (eds.) IInd National Applied Psychology Conference of $\mathrm{PhD}$ Students: Abstracts. [Kórházi betegek betegségreprezentációinak megjelenítése a PRISM-D rajzteszt használatával. In: Kővágó P, Vass Z, Vargha A. (szerk.) II. Országos Alkalmazott Pszichológiai PhD-Hallgatói Konferencia: Előadás-kivonatok.] Károli Gáspár Református Egyetem, Budapest, 2013; p. 32. [Hungarian]

[18] Havancsák R, Pócza-Véger P, Csabai M. The PRISM-D drawing test in the examination and treatment of hospital patients. In: Csabai M, Pintér JN. (eds.) Psychology in healing: Phenomenological, art psychological and body representation centered approaches. [A PRISM-D rajzteszt kórházi betegek vizsgálatában és kezelésében. In: Csabai M, Pintér JN. (szerk.) Pszichológia a gyógyításban. Fenomenológiai, művészetpszichológiai és testkép-központú megközelítések.] Oriold és Társai Kiadó, Budapest, 2013; pp. 83-107. [Hungarian]

[19] Büchi S, Sensky T. PRISM: Pictorial Representation of Illness and Self Measure. A brief nonverbal measure of illness impactand therapeutic aid in psychosomatic medicine. Psychosomatics 1999; 40: 314-320.

[20] Reimus JL, Vingerhoets AJ, Soons PH, et al. Suffering in psoriasis patients: its relation with illness severity and subjective wellbeing. Int J Dermatol. 2007; 46: 1042-1045.

[21] Büchi S, Sensky T, Sharpe L, et al. Graphic representation of illness: a novel method of measuring patients' perceptions of the impact of illness. Psychother Psychosom. 1998; 67: 222-225.
[22] Niedermann K, Büchi S, Ciurea A, et al. Six and 12 months' effects of individual joint protection education in people with rheumatoid arthritis: A randomized controlled trial. Scand J Occup Ther. 2012; 19: 360-369.

[23] Sándor Z, Csabai M. Complex examination of illness representations of patients with breast cancer. In: Koncz I, Szova I. (eds.) (More) Authentical scientific presentations, vol. 2. PEME (Association of Professors for the European Hungary) VIIIth PhD Conference. [Emlődaganatos betegek betegségreprezentációinak több szempontú vizsgálata. In: Koncz I, Szova I. (szerk.) Hiteles(ebb) tudományos prezentációk, II. kötet: PEME VIII. PhD-Konferencia.] Professzorok az Európai Magyarországért Egyesület, Budapest, 2014; pp. 26-37. [Hungarian]

[24] Sándor Z, Czinderi K, Csabai M. Connections between illness representations, postoperative pain and social support on the PRISM-D nonverbal test in case of newly operated patients with breast cancer. In: Vargha A. (ed.) The world of our relationships: XXII. National Scientific Congress of the Hungarian Psychological Association: Abstract book. [Betegségreprezentációk, mútét utáni fájdalom és társas támogatás összefüggései a PRISMD nonverbális teszten frissen operált emlődaganatos betegeknél. In: Vargha A. (szerk.) Kapcsolataink világa: Magyar Pszichológiai Társaság XXII. Országos Tudományos Nagygyúlés: Kivonatkötet.] Magyar Pszichológiai Társaság, Budapest, 2013; p. 265. [Hungarian]

\section{„Dum spiro, spero." (Amíg élek, remélek.)}

